\title{
PENINGKATAN HASIL DAN KEAKTIFAN BELAJAR SISWA MELALUI NHT
}

\author{
Gebi Yustika', Erlina Prihatnani \\ 1,2 Pendidikan Matematika Universitas Kristen Satya Wacana, Jalan Diponegoro No. 52-60 Salatiga \\ 202016020@student.uksw.edu
}

\begin{abstract}
Inappropriate learning processes can lead to low learning results and student inactivity. This research (PTK) aims to improve learning outcomes and activeness of students in VIIH class of SMP Negeri 6 Salatiga students in rectangular and triangular material through Numbered Heads Together (NHT) learning application model. The model used in this research is Kemmis \& Mc Taggart spiral model. It shows that the average result in the class is 64,4 (have not reach the minimum requirement) with percentage in passing the requirement of $46.40 \%$. In cycle 2, the result increased with passing the average grade of 81.2 (fulfilling KKM) with percentage of $75 \%$ for passing grade requirement. Student activeness is increasing along with the learning outcomes. However, average category or high category on the 1 st cycle is at $50,14 \%$, while on the $2^{\text {nd }}$ cycle, it can reach out to $80 \%$ or more. The two results concluded that implementing NHT could improve learning outcomes and activeness of students in VIIH class of SMPN 6 Salatiga.
\end{abstract}

Keywords: NHT, Learning Result, Students Activeness, Rectangular, Triangular

\begin{abstract}
Abstrak
Rendahnya hasil belajar dan ketidakaktifan siswa dapat disebabkan karena proses pembelajaran yang tidak tepat. Penelitian tindakan kelas (PTK) ini bertujuan untuk meningkatkan hasil belajar dan keaktifan siswa kelas VII H SMP Negeri 6 Salatiga pada materi segiempat dan segitiga melalui penerapan model pembelajaran Numbered Heads Together (NHT). Model penelitian yang digunakan adalah model spiral Kemmis \& Mc Taggart. Hasil penelitian menunjukkan bahwa rata-rata kelas adalah 64,4 (belum mencapai KKM) dengan persentase ketuntasan sebesar 46,40\%. Hasil tersebut meningkat pada siklus 2 dengan pencapaian rata-rata kelas menjadi 81,2 (memenuhi KKM) dengan presentasi ketuntasan sebesar 75\%. Seperti halnya hasil belajar, keaktifan siswa juga mengalami peningkatan. Pada siklus 1 yang masuk kategori sedang atau tinggi 50,14\% sedangkan pada siklus 2 mencapai $80 \%$ lebih siswa yang keaktifan masuk kategori sedang ataupun tinggi. Berdasarkan kedua hasil tersebut maka dapat disimpulkan bahwa penerapan NHT dapat meningkatkan hasil belajar dan keaktifan siswa kelas VII H SMPN 6 Salatiga.
\end{abstract}

Kata Kunci: NHT, Hasil Belajar, Keaktifan Siswa, Segiempat dan Segitiga

Mengajar adalah proses yang kompleks, dimana tidak hanya sekedar penyampaian informasi dari guru kepada siswa, tetapi mengajar terdiri dari sejumlah kegiatan (Ali, 1984: 2). Teori konstruktivisme memaknai belajar sebagai proses aktif siswa dalam mengkonstruksi pengetahuan. Siswa tidak hanya menerima apa yang diberi oleh instruktur, tetapi siswa mengkonstruksi pengetahuan sendiri (Hamdani, 2011: 65). Zamroni (2000:74) mengatakan "guru berperan penting dalam proses belajar mengajar". Dalam proses belajar mengajar guru adalah orang yang bertanggungjawab untuk mengembangkan suasana bebas bagi siswa untuk mengkaji apa yang menarik, mengekspresikan ideide dan kreatifitasnya.

Proses belajar mengajar adalah proses yang di dalamnya terdapat komunikasi timbal balik yang berlangsung dalam situasi edukatif untuk mencapai tujuan pembelajaran (Rustaman, 2011: 461). Setiap proses belajar mengajar selalu menghasilkan hasil belajar. Keberhasilan belajar mengajar dipengaruhi oleh berbagai faktor, yaitu tujuan, guru, siswa, kegiatan pengajaran, bahan dan alat evaluasi, serta suasana evaluasi (Djamarah dan Zain, 2010: 109).

Dalam standar proses (Permendikbud No 22 Thn 2016) disebutkan bahwa salah satu prinsip 
pembelajaran adalah dari siswa diberi tahu menuju siswa mencari tahu, dari guru sebagai satu-satunya sumber belajar menjadi belajar berbasis aneka sumber belajar. Hal ini menunjukkan bahwa siswa dituntut untuk aktif. Meskipun standar proses tersebut sudah diputuskan dalam kurikulum 2013 yang diterapkan secara bertahap sejak tahun 2014, namun tidak semua proses pembelajaran telah sepenuhnya sesuai dengan standar proses. Salah satu contohnya adalah pembelajaran matematika di SMPN 6 Salatiga.

Hasil observasi menunjukkan bahwa proses pembelajaran diawali dengan penyampaian materi dilanjutkan pemberian contoh dan latihan soal. Peran guru sebagai sumber informasi utama bagi siswa tampak dominan, jika dibandingkan dengan peran siswa dalam proses pembelajaran. Kebanyakan siswa tidak aktif dalam pembelajaran. Fokus siswa hanya tampak pada saat guru memberikan penjelasan di awal-awal, namun setelah memasuki pembahasan contoh soal, hanya tinggal beberapa siswa yang tetap fokus memperhatikan. Ketidakfokusan siswa tampak dari mulainya beberapa siswa ngobrol di luar topik pembelajaran, bermain alat tulis, melihat ke depan namun dengan pandangan yang kosong atau bahkan dengan sengaja melakukan hal-hal yang bertujuan mengganggu teman sehingga menimbulkan situasi kelas yang tidak kondusif

Begitu juga saat mendapatkan tugas latihan soal. Hanya sedikit siswa yang mencoba berpikir untuk mengerjakan, sedangkan siswa lainnya cenderung mengerjakan hanya dengan melihat pekerjaan teman dan bukan berdiskusi. Inisiatif siswa untuk bertanya, ataupun mengungkapkan pendapat selama proses pembelajaran juga masih rendah. Pada saat diberi kesempatan untuk mengerjakan di depan, siswa yang tergolong pandai yang mendominasi untuk mengerjakan di depan. Selain itu, jika diberikan tugas untuk dikerjakan di rumah, tidak semua siswa mengerjakan. Sebagian besar siswa hanya mencontek hasil pekerjaan teman itupun dilakukan di kelas sebelum proses pembelajaran berlangsung. Ketidakaktifan siswa juga nampak dari tidak mencatatnya beberapa siswa akan materi-materi penting yang disampaikan guru. Hal ini menunjukkan bahwa tidak semua siswa aktif dalam proses belajar. semua siswa aktif dalam proses belajar.

Selain permasalahan tidak aktifnya siswa dalam mengikuti proses belajar, terdapat permasalahan lain yaitu rendahnya hasil belajar siswa. Siswa hanya mencapai rata-rata hasil belajar 52,25. Rata-rata tersebut jauh dari KKM yang ditetapkan yaitu 75 dan bahkan semua siswa belum mencapai KKM.

Keaktifan belajar siswa adalah unsur yang berperan penting dalam keberhasilan suatu proses belajar mengajar. Seperti yang dijelaskan oleh Dimyati \& Mudjiono (2010:51) bahwa untuk memproses dan dapat mengolah perolehan belajarnya secara efektif siswa dituntut aktif secara fisik, intelektual, dan emosional. Diedrich (Hendriana dkk, 2018: 160) menggolongkan indikator keaktifan belajar siswa berdasarkan jenis aktivitasnya yaitu 1) Kegiatan visual; 2) Kegiatan lisan; 3) Kegiatan mendengarkan; 4) Kegiatan menulis; 5) Kegiatan menggambar; 6) Kegiatan motorik; 7) Kegiatan mental; dan 8) Kegiatan emosional.

Dengan melihat permasalahan di kelas VII H SMPN 6 Salatiga, maka dibutuhkan suatu upaya 
untuk mengatasi masalah tersebut. Salah satunya dengan menerapkan model pembelajaran yang menekankan pada peningkatan hasil belajar dan meningkatkan keaktifan siswa. Model pembelajaran kooperatif memiliki peluang untuk menciptakan hal tersebut. Oleh karena permasalahan yang ditemukan adalah keaktifan belajar siswa yang masih terbatas pada siswa-siswa tertentu, maka penelitian ini memilih Numbered Heads Together (NHT) sebagai salah satu tipe cooperative learning sebagai upaya untuk mengatasi permasalahan tersebut.

NHT merupakan salah satu model pembelajaran kooperatif yang banyak melibatkan keaktifan siswa. Slavin (2005: 256) memaparkan NHT adalah sebuah group discussion, dimana satu siswa yang akan terpilih menjadi wakil kelompok. Tetapi sebelumnya tidak diberi tahu siapa yang menjadi wakil kelompok tersebut. Selain itu menurut Hamdani (2011: 89), NHT adalah metode belajar dimana siswa dibagi dalam beberapa kelompok dan setiap siswa diberi nomor, kemudian guru melakukan pemanggilan nomor secara acak. Berikut sintak NHT dari berbagai sumber.

\section{Tabel 1.}

Sintak Numbered Heads Together (NHT)

\begin{tabular}{llll}
\hline \multicolumn{1}{c}{ Trianto (2009: 82) } & $\begin{array}{l}\text { Slavin (2005: 255) \& Suprijono } \\
(2013: 92)\end{array}$ & $\begin{array}{l}\text { Sani (2013: 188) \& Hamdani, } \\
(2011: 90)\end{array}$ \\
\hline Penomoran & $\begin{array}{l}\text { Pembagian Kelompok } \\
\text { Pemberian Identitas }\end{array}$ & $\begin{array}{l}\text { Pembagian Kelompok dan } \\
\text { Pemberian Identitas }\end{array}$ & \\
\hline Mengajukan Pertanyaan & Mengajukan Pertanyaan & Guru memberikan tugas & \\
\hline Berpikir Bersama & Berpikir Bersama & Berpikir Bersama \\
\hline Menjawab & Pemanggilan Nomor & $\begin{array}{l}\text { Pemanggilan Nomor } \\
\text { Tanggapan Kelompok lain }\end{array}$ \\
& Menjawab Pertanyaan & $\begin{array}{l}\text { Simpulkan } \\
\end{array}$ & \\
\hline
\end{tabular}

Dari langkah pembelajaran NHT di atas, dapat dikategorikan terdapat empat garis besar langkah yang harus ada di NHT yaitu pembagian kelompok sekaligus pemberian identitas penomoran, pembagian tugas/ pengajuan pertanyaan, berpikir bersama (Heads Together), dan pengajuan jawaban dengan pemanggilan nomor yang diikuti tanggapan kelompok.

Melalui pembelajaran NHT dimungkinkan setiap siswa terpanggil secara acak untuk mewakili kelompok. Hal ini dapat menjadi cara untuk dapat membuat setiap siswa terlibat aktif saat diskusi dalam kelompok. Selain itu NHT memiliki kelebihan yaitu dapat berlangsung diskusi yang sungguh-sungguh dimana siswa yang lebih pandai dapat mengajari siswa yang kurang pandai (Hamdani, 2011: 90).

Beberapa penelitian juga membuktikan bahwa penerapan NHT dapat meningkatkan hasil belajar. Misalnya, penelitian yang telah dilakukan oleh Alie (2013), Aniza (2017), Destiyandani (2016) yang berturut-turut diterapkan pada materi Jarak pada Bangun Ruang pada siswa kelas X, Perbandingan pada siswa kelas VII, dan Segitiga pada siswa kelas VII. Selain itu, NHT juga telah terbukti dapat digunakan untuk meningkatkan keaktifan siswa, seperti yang disimpulkan dalam penelitian Maisyrah (2015) dan Sudarto (2017) berturut-turut pada materi bentuk akar dan logaritma pada siswa kelas X dan materi sifat pertukaran pada perkalian pada siswa kelas II.

Hasil penelitian tersebut makin memperkuat pemilihan NHT sebagai upaya untuk mengatasi 
permasalahan yang ditemukan pada kelas VII H SMPN 6 Salatiga. Diharapkan dengan penerapan NHT dapat memfasilitasi semua siswa untuk terlibat aktif sehingga dapat meningkatkan hasil belajar dan kekatifan siswa. Selain itu, penelitian ini juga diharapkan dapat memberikan informasi akan teori-teori NHT, serta dapat memberi gambaran tentang penerapan NHT pada pembelajaran matematika pada materi segiempat dan segitiga untuk siswa kelas VII H SMPN 6 Salatiga, sehingga diharapkan hal tersebut dapat menginspirasi guru untuk menerapkan NHT baik pada materi lain maupun mata pelajaran lainnya.

\section{METODE}

Jenis penelitian ini adalah Penelitian Tindakan Kelas (PTK). Model atau desain penelitian yang diterapkan dalam penelitian ini adalah model spiral yang dikemukakan oleh Kemmis dan MC Taggart (Sukardi, 2013: 7).

Penelitian ini dilakukan di kelas VII H SMP Negeri 6 Salatiga yang berlokasi di Jl. Tegalrejo Raya, Tegalrejo, Kec. Argomulyo, Kota Salatiga, Jawa Tengah. Subjek Penelitian Tindakan Kelas ini adalah siswa kelas VII H yang berjumlah 28 siswa yang terdiri dari 11 siswa laki-laki dan 17 siswa perempuan. Penelitian dilakukan pada bulan Januari 2019 hingga Juni 2019. Penelitian ini dilaksanakan dalam siklus yang berhenti apabila memenuhi semua syarat, yaitu; (1) rata-rata nilai hasil belajar siswa mencapai KKM yang ditetapkan yaitu 75, (2) ketuntasan kelas mencapai minimal 75\%, (3) keaktifan siswa kategori tinggi ataupun sedang mencapai minimal $80 \%$.

Teknik pengumpulan data yang digunakan meliputi observasi kelas VII H pada pembelajaran matematika, dokumentasi, tes, dan angket. Angket terdiri dari delapan indikator keaktifan belajar siswa yaitu kegiatan visual, lisan, mendengarkan, menulis, menggambar, motoric, mental, dan emosional.

\section{HASIL}

\section{Pra Siklus}

Hasil observasi pembelajaran di kelas VII H SMPN 6 Salatiga menunjukkan terbatasnya fokus siswa terhadap penjelasan guru (hanya di awal-awal pembelajaran), tidak adanya proses diskusi antara teman sebaya untuk memahami materi, adanya dominasi siswa-siswa tertentu (siswa pandai) dalam mengerjakan soal, adanya proses sekedar mencontek pekerjaan teman tanpa adanya proses pemahaman. Hal-hal tersebut menunjukkan belum optimalnya keaktifan siswa. Selain permasalahan tidak aktifnya siswa dalam mengikuti proses belajar, terdapat permasalahan lain yaitu rendahnya hasil belajar siswa. Siswa hanya mencapai rata-rata hasil belajar 52,25 (belum mencapai KKM).

\section{Siklus 1}

\section{Perencanaan (planning)}

Pada tahap ini dilakukan analisis terhadap kurikulum yang meliputi analisis $\mathrm{KI}, \mathrm{KD}$, perumusan instrumen, penentuan cakupan materi dan penentuan alokasi waktu pembelajaran. Produk dari analisis ini adalah terciptanya instrume pembelajaran yang kemudian dituangkan dalam RPP yang dilengkapi media pembelajaran berupa LKPD (Lembar Kerja Peserta Didik), alat peraga dan power point. Tidak hanya mencakup materi, disiapkan pula video-video untuk menanamkan nilai-nilai karakter. Selain 
menganalisis kurikulum dan menyusun perangkat pembelajaran, pada tahap ini juga disusun lembar observasi guru, angket keaktifan, evaluasi tes beserta lembar validasi yang digunakan untuk proses validasi. Proses validasi untuk semua nstrument juga dilakukan pada tahap ini.

\section{Tindakan (acting)}

Pada tahap ini peneliti berperan sebagai guru sedangkan sebagai observer adalah guru matematika. Pelaksanaan tindakan pada siklus 1 terbagi menjadi 5 pertemuan dengan total 12 JP dimana pada setiap pertemuan terbagi menjadi 3 kegiatan yaitu kegiatan pendahuluan, inti, dan penutup.

\section{Kegiatan Pendahuluan}

Kegiatan pembelajaran dalam setiap siklusnya mengacu pada standar proses pembelajaran yang diatur dalam Permendiknas nomor 22 tahun 2016 yang terbagi atas 5 kegiatan yaitu diawali dengan penyiapan peserta didik secara psikis dan fisik, pennyampaian informasi akan manfaat kontekstual, pengajuan pertanyaan yang berhubungan dengan materi sebelumnya, penyampaian tujuan pembelajaran serta penyampaian cakupan materi dan langkah-langkah pembelajaran yang akan dilakukan.

Menyapa, menanyakan kabar, menanyakan hal yang patut disyukuri, memimpin gerakan kegiatan lima menit memungut sampah, menginstruksikan pengaturan posisi duduk setiap kelompok, mengintruksikan penyiapan buku dan peralatan belajar matematika, serta menyangkan video motivasi merupakan kegiatan-kegiatan rutin sebagai bentuk menyiapkan peserta didik secara fisik dan psikis. Di setiap pertemuan, juga selalu disampaikan manfaat kontekstual akan pentingnya materi yang dipelajari. Contohnya saat akan mempelajari perbedaan sifat segiempat dan segitiga guru menampilkan gambar 3 jenis rambu lalu lintas (petunjuk, peringatan, dan larangan) yang ternyata setiap jenisnya memiliki bentuk bangun berbeda. Saat akan belajar pengidentifikasian sifat-sifat berbagai macam segiempat, guru menampilkan bagaimana pentingnya mengidentifikasi persamaan dan perbedaan sifat dalam mendesain benda seperti saat mendesain ukuran keramik untuk dinding dan lantai, mendesain kapal dengan melihat bentuk ikan, dan mendesain pesawat terbang dengan melihat bentuk burung.

Guru juga menyampaikan tujuan pembelajaran yang akan dicapai melalui tampilan di PPT. Adapun tujuan pembelajaran pada pertemuan pertama, kedua sampai pertemuan kelima secara berturut-turut yaitu mengidentifikasi gambar benda-benda kontekstual dan gambar bangun datar; membuktikan jumlah sudut segiempat dan segitiga; mengidentifikasi sifat-sifat bangun datar segiempat dan segitiga; menyelesaikan permasalahan sifat-sifat segiempat dan segitiga; serta melakukan evaluasi dengan pemberian posttest akhir Siklus 1. Cakupan materi yang akan dipelajari dalam bentuk peta konsep. Di setiap pertemuan, guru juga menyampaikan langkah pembelajaran NHT yaitu penyampaian materi, diskusi kelompok, pemanggilan nomor dan penyampaian jawaban. Guru selalu menekankan di awal pembelajaran bahwa pemanggilan nomor dilakukan acak dan yang terpilih harus mandiri dan tanpa membawa catatan untuk mendorong siswa aktif saat diskusi dalam kelompok.

\section{Kegiatan Inti}

Proses pembelajaran selalu menggunakan model NHT berbantu media PPT dan LKPD pada setiap pertemuannya. Pada kegiatan ini diawali dengan penyampaian inti materi yang dilakukan dengan 
metode tanya jawab sehingga siswa tetap dapat fokus dikarenakan guru sering mengajukan pertanyaanpertanyaan yang dapat menstimulus siswa untuk berpikir dan menjawab pertanyaan. Guna memperdalam pemahaman siswa, proses pembelajaran dilanjutkan dengan kegiatan diskusi kelompok. Topik diskusi di setiap kelompok sama. Proses pemanggilan nomor dilakukan acak dengan alat bantu "jobstick".

Pada pertemuan pertama terdapat dua kali diskusi yaitu aktivitas mengidentifikasi bangun-bangun datar ke dalam 3 kelompok (segitiga/ segiempat/ bukan keduanya) dan mengerjakan soal macammacam bangun datar. Total pemanggilan nomor pada pertemuan pertama sebanyak 2 kali. Pertemuan kedua terdapat dua kali diskusi yaitu melakukan pembuktian jumlah sudut segiempat dan segitiga dan mengambil bangun-bangun datar dari kertas plano pada pertemuan 1 sesuai dengan kartu bangun datar yang diperoleh dan total pemanggilan nomor pada pertemuan kedua sebanyak 2 kali. Pada pertemuan ketiga dan keempat masing-masing satu kali diskusi dan satu kali pemanggilan nomor dengan materi diskusi berturut-turut yaitu mengidentifikasi sifat-sifat bangun datar dari hasil kegiatan diskusi kedua pada pertemuan kedua dan menyelesaikan masalah terkait sifat-sifat segitiga dan segiempat.

\section{Kegiatan Penutup}

Pada kegiatan penutup terdapat empat kegiatan yang dilakukan berulang-ulang pada setiap pertemuan. Keempat kegiatan tersebut adalah refleksi atas aktivitas yang sudah dilakukan dan pemahaman akan materi yang telah dipelajari, pemberian umpan balik, rencana tindak lanjut, dan memberikan informasi untuk pertemuan selanjutnya. Contoh pertanyaan yang diajukan sebagai bentuk refleksi adalah “Apa yang sudah kita pelajari hari ini? Apa yang belum kalian pahami?". Guru mengecek pemahaman siswa melalui pengajuan pertanyaan-pertanyaan terkait materi yang telah dipelajari. Bentuk umpan balik lainnya adalah penyampaian informasi dari guru tentang hal-hal positif yang telah ditunjukkan siswa selama pembelajaran berlangsung, seperti pengumuman kelompok yang paling aktif dan penyebutan siswa yang mengalami perubahan positif. Selain itu, guru juga memberikan satu soal HOTS sebagai pemikiran lebih lanjut dalam siswa belajar di rumah. Di akhir kegiatan penutup guru tidak lupa menyampaikan rencana tindak lanjut yaitu pembelajaran yang akan dilakukan pada pertemuan berikutnya.

\section{Pengamatan (observing)}

Setiap proses pembelajaran dilakukan pengamatan dengan pengisian lembar observasi guru sebagai instrumen pengamatan. Hasil rekapitulasi observasi guru pada siklus 1 dapat dilihat pada Tabel 2.

\section{Tabel 2}

Hasil Rekapitulasi Lembar Observasi Guru Siklus 1

\begin{tabular}{llll}
\hline No & Aspek yang diamati & Persentase & Kategori \\
\hline 1. & Kesesuaian dengan RPP & $91,25 \%$ & Sangat Baik \\
\hline 2. & Kesesuaian dengan sintak model NHT & $84,38 \%$ & Sangat Baik \\
\hline 3. & Penguasaan Kelas & $93,75 \%$ & Sangat Baik \\
\hline 4. & Penguasaan materi & $87,50 \%$ & Sangat Baik \\
\hline 5. & Sikap, penampilan, tulisan, dan tutur kata & $90,00 \%$ & Sangat Baik \\
\hline
\end{tabular}


Berdasarkan Tabel 2 tampak bahwa kelima aspek masuk kategori sangat baik. Hal itu dikarenakan adanya kesesuaian pembelajaran dengan sintak NHT, efektifnya proses diskusi dan berhasilnya proses pemanggilan nomor. Namun masih terdapat beberapa hal yang belum mendapat nilai optimal, seperti ketidaksesuaian dengan RPP. Hal ini dikarenakan tidak semua tujuan yang dirancang dapat tercapai di pertemuan tersebut. Selain pencapaian tujuan yang belum sesuai dengan alokasi waktu yang dirancang, ada pula hal yang belum maksimal yaitu pembagian kelompok. Pembagian kelompok yang hanya berdasarkan nilai tanpa melihat karakteristik siswa belum dapat membagi kelompok secara tepat. Hal ini tampak dari adanya satu kelompok yang 2 dari 5 anggotanya adalah siswa yang mudah kehilangan fokus belajar dan sering saling mengganggu sehingga keberadaan mereka membuat situasi kerja dalam kelompok tidak kondusif.

Perolehan hasil belajar pada siklus 1 dapat dilihat pada Tabel 3. Pelaksanaan pembelajaran pada siklus 1 menghasilkan rata-rata 64,4. Hasil tersebut belum mencapai KKM yang ditetapkan yaitu 75 . Selain itu ketuntasan kelas baru mencapai $46,4 \%$ belum mencapai persentase ketuntasan belajar klasikal minimal yang diharapkan yaitu $75 \%$.

\section{Tabel 3}

Hasil Belajar Siswa Siklus 1

\begin{tabular}{cccccccc}
\hline \multirow{2}{*}{ Jml } & \multicolumn{2}{c}{ Nilai } & Rata- & \multicolumn{2}{c}{ tuntas } & \multicolumn{2}{c}{ tdk tuntas } \\
\cline { 2 - 3 } \cline { 7 - 8 } & max & $\min$ & rata & Jml & $(\%)$ & Jml & $(\%)$ \\
\hline 28 & 93 & 44.5 & 64.4 & 13 & 46.4 & 12 & 53.6 \\
\hline
\end{tabular}

Adapun rekapitulasi hasil pengukuran keaktifan siswa berdasarkan pengamatan dan pengisian angket dapat dilihat pada Tabel 4. Tabel 4 menunjukkan bahwa masih terdapat

\section{Tabel 4}

Hasil Keaktifan Siswa Siklus 1

\begin{tabular}{ccc}
\hline Kriteria & $\begin{array}{c}\text { Jumlah } \\
\text { siswa }\end{array}$ & Presentase \\
\hline Tinggi & 2 & $7,14 \%$ \\
\hline Sedang & 12 & $42,86 \%$ \\
\hline Rendah & 14 & $50 \%$ \\
\hline
\end{tabular}

banyak siswa yang masuk dalam keaktifan dengan kategori rendah yaitu $50 \%$.

\section{Refleksi (Reflecting)}

Berdasarkan tahap pelaksanaan dan pengamatan, maka diperoleh beberapa hal yang sudah baik dan beberapa hal yang masih perlu diperbaiki. Kelebihan pada siklus 1 yaitu poses pembelajaran telah berhasil menumbuhkan semangat siswa dan membuat setiap siswa aktif dalam proses pembelajaran baik saat proses penyampaian materi melalui metode tanya jawab, maupun proses pemahaman materi melalui tahap diskusi kelompok dan juga tahap pemanggilan nomor. Pembelajaran dengan berbagai aktifitas siswa telah berhasil membuat sebagian besar siswa tetap fokus dalam pembelajaran. Kekonsistenan untuk menampilkan video/ gambar motivasi juga dapat menambah kekompakan dan solidaritas kelompok. Selain itu, proses pembelajaran sudah berhasil menciptakan suasana belajar yang lebih kondusif dengan sistem pemberian reward dan punishment dalam bentuk "cap jempol". Namun bagi siswa yang terlanjur mendapat punishment berupa "jempol terbalik" banyak, sistem ini tidak berhasil membuat efek jera dan justru membuat siswa menyerah dan cenderung bertindak sesukanya. Adapun kelemahan lain adalah pembagian kelompok. Masih terdapat satu kelompok tidak kondusif. 
Dari sisi perancangan kegiatan proses pembelajaran, perlu adanya rancangan tujuan yang harus disesuaikan dengan alokasi waktu dan kemampuan siswa.

\section{Siklus 2}

\section{Perencanaan (planning)}

Pada siklus 1 kekompakan antara anggota kelompok dan semangat berjuang untuk keberhasilan kelompok sudah mulai terbangun di setiap kelompok. Oleh karena itu, pada siklus 2 tidak dilakukan perubahan kelompok. Namun untuk mengatasi ketidakkondusifan di satu kelompok, maka guru mengatur posisi duduk dari anggota kelompok tersebut sehingga 2 siswa yang sering saling mengganggu tidak duduk bersebelahan. Selanjutnya, memulai sistem perhitungan reward dan punishment dari awal. Hal ini diharapkan dapat menumbuhkan kembali semangat bagi siswa-siswa yang sudah terlanjur mendapat punishment lebih banyak daripada reward. Selain itu, pada siklus 2 tetap mempertahankan perancangan skenario pembelajaran dengan berbagai kegiatan yang berfokus pada siswa dengan tetap menggunakan berbagai media seperti LKPD, power point, video dan alat peraga dengan tetap disesuaikan dengan karakter materi dan siswa.

\section{Tindakan (acting)}

Pada pelaksanaan tindakan siklus 2 terbagi menjadi 4 pertemuan dengan total 10 JP dimana seperti siklus 1 pada setiap pertemuan juga terbagi menjadi 3 kegiatan yaitu kegiatan pendahuluan, inti, dan penutup.

\section{Kegiatan Pendahuluan}

Seperti halnya pada siklus 1 , kegiatan pendahuluan pada siklus 2 juga terbagi menjadi 5 kegiatan. Adapun tujuan pembelajaran pada pertemuan pertama sampai pertemuan keempat secara berturut-turut yaitu menentukan keliling pada bangun-bangun kontekstual; menentukan keliling pada bangun-bangun datar dengan memperhatikan sifat-sifat; menentukan keliling bangun-bangun datar tak beraturan; dan melakukan evaluasi dengan pemberian posttest akhir siklus 2

\section{Kegiatan Inti}

Model pembelajaran yang digunakan pada siklus 2 masih sama dengan yang digunakan pada siklus 1 yaitu model pembelajaran NHT yang didukung dengan LKPD serta PPT. Pada kegiatan ini, tetap dilakukan diskusi dan pemanggilan nomor. Terdapat 3 kali diskusi dan total pemanggilan nomor sebanyak 3 kali. Adapun topik diskusi pada siklus 2 yaitu menentukan keliling pada bangun-bangun kontekstual menggunakan tali dan penggaris; menentukan keliling pada bangun datar dengan memperhatikan sifat-sifat; menentukan keliling bangun datar tidak beraturan.

\section{Kegiatan Penutup}

Seperti pada siklus 1, siklus 2 juga terdapat empat kegiatan yang dilakukan berulang-ulang pada setiap pertemuannya. Kegiatan tersebut yaitu melakukan refleksi mengenai aktivitas yang sudah dilakukan dan materi yang telah dipelajari, pemberian umpan balik, rencana tindak lanjut, dan memberikan informasi untuk pertemuan selanjutnya 
Rekapitulasi hasil observasi aktivitas guru dapat dilihat pada Tabel 5. Tampak bahwa bahwa kesesuaian dengan RPP, kesesuaian dengan sintak model NHT, sikap penampilan tulisan dan tutur kata mengalami peningkatan daripada siklus 1, bahkan kemampuan guru dalam penguasaan kelas dan materi mendapat point maksimal yaitu $100 \%$.

\section{Tabel 5}

Hasil Rekapitulasi Lembar Observasi Guru Siklus 2

\begin{tabular}{clll}
\hline No & Aspek yang diamati & Persentase & Kategori \\
\hline 1. & Kesesuaian dengan RPP & $97,92 \%$ & Sangat Baik \\
\hline 2. & Kesesuaian dengan sintak model NHT & $98,87 \%$ & Sangat Baik \\
\hline 3. & Penguasaan kelas & $100 \%$ & Sangat Baik \\
\hline 4. & Penguasaan materi & $100 \%$ & Sangat Baik \\
\hline 5. & Sikap, penampilan, tulisan, dan tutur kata & $97,50 \%$ & Sangat Baik \\
\hline
\end{tabular}

Perolehan hasil belajar pada siklus 2 dapat dilihat pada Tabel 6. Setelah melaksanakan pembelajaran pada siklus 2 menggunakan model pembelajaran NHT, rata-rata hasil belajar siswa telah mencapai 81,2. Sementara ketuntasan kelas telah mencapai $75 \%$. Hasil tersebut telah mencapai indikator untuk aspek ketuntasan kelas yaitu $75 \%$.

Tabel 6

Hasil Belajar Siswa Siklus 2

\begin{tabular}{ccccccccc}
\hline \multirow{2}{*}{ Jml } & \multicolumn{2}{c}{ Nilai } & \multirow{2}{*}{ Rata- } & \multicolumn{2}{c}{ tuntas } & \multicolumn{2}{c}{ tdk tuntas } \\
\cline { 2 - 3 } \cline { 6 - 8 } & max & $\min$ & rata & Jml & $(\%)$ & Jml & $(\%)$ \\
\hline 28 & 100 & 48 & 81.2 & 21 & 75 & 7 & 25 \\
\hline
\end{tabular}

Perolehan rekapitulasi hasil keaktifan siswa pada siklus

2 dapat dilihat pada Tabel 7. Berdasarakan Tabel 7, tampak

bahwa yang masuk kategori tinggi sebesar 32,15\% dan kategori sedang sebesar 53,57\% sehingga total yang masuk kategori minimal sedang $85,72 \%$. Hal ini berarti hasil keaktifan siswa mengalami peningkatan dari siklus 1 dan telah hasil tersebut telah mencapai indikator keberhasilan.

\section{Refleksi (reflecting)}

Pelaksanaan siklus 2, telah menghasilkan peningkatan baik hasil belajar maupun keaktifan siswa. Kelebihan pada siklus 2 yaitu sudah terbangun budaya karakter yang baik seperti menjaga kebersihan lingkungan kelas, solidaritas di dalam kelompok, dan kepercayaan diri siswa dalam menyampaikan pendapat baik lisan maupun tertulis. Strategi guru dalam mengatur posisi duduk dari anggota kelompok yang sering saling mengganggu dengan duduk tidak bersebelahan, telah berhasil menciptakan kelas yang kondusif. Selain itu, siswa yang banyak mendapatkan "cap jempol terbalik" pada siklus 1 dengan memulai sistem perhitungan dari awal pada siklus 2 membuat siswa kembali bersemangat. Namun, kelemahan pada siklus 2 yaitu beberapa siswa tidak membawa nametag saat pembelajaran matematika, sehingga saat pemanggilan nomor identitas penomoran kelompok harus melihat dari tampilan PPT.

\section{Deskripsi Antar Siklus}

Hasil belajar dari kedua tindakan tersebut mengalami peningkatan yang cukup signifikan apabila 
dibandingkan dari siklus 1 ke siklus 2. Pada Tabel 8, dapat dilihat bahwa nilai rata-rata kelas dari siklus 1 ke siklus 2 mengalami peningkatan.

\section{Tabel 8}

Perbandingan Hasil Belajar Antar Siklus

\section{Siklus Jumlah Siswa Nilai Tertinggi Nilai Terendah Nilai Rata-Rata Kelas}

\begin{tabular}{ccccc}
\hline Siklus 1 & 28 & 93 & 44,4 & 64,4 \\
\hline Siklus 2 & 28 & 100 & 48 & 81,2 \\
\hline
\end{tabular}

Adapun perbandingan hasil belajar siswa siklus 1 dengan siklus 2 dapat dilihat pada Gambar 1 .

Berdasarkan hasil tersebut tampak bahwa persentase ketuntasan hasil belajar pada siklus 1 adalah 46,40\% sedangkan pada siklus 2 naik menjadi 75\% dan pencapaian ini telah mencapai indikator keberhasilan. Perbandingan keaktifan belajar siswa ditunjukkan pada Gambar 2. Pada Gambar 2, tampak bahwa persentase keaktifan siswa siklus 1 kategori rendah adalah 50\% dan pada siklus 2 persentase keaktifan siswa kategori rendah hanya 14,38\%. Dari hasil tersebut menunjukkan bahwa keaktifan siswa pada siklus 2 mengalami peningkatan dengan 85,57\% siswa masuk kategori minimal sedang.

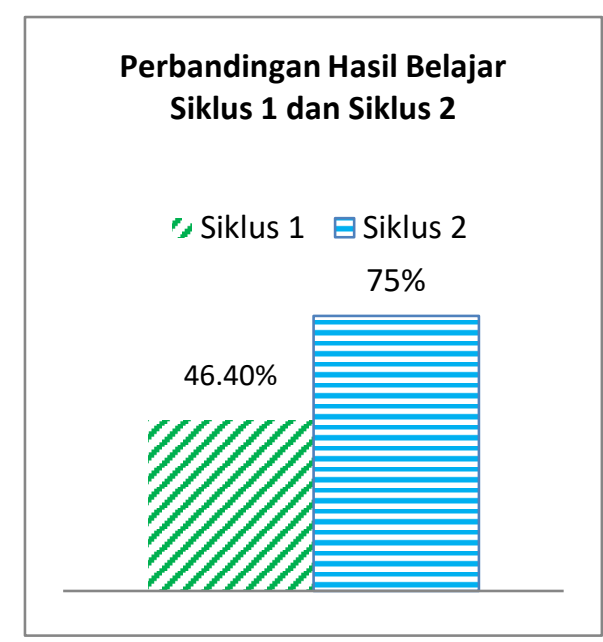

Gambar 1. Perbandingan Hasil Belajar

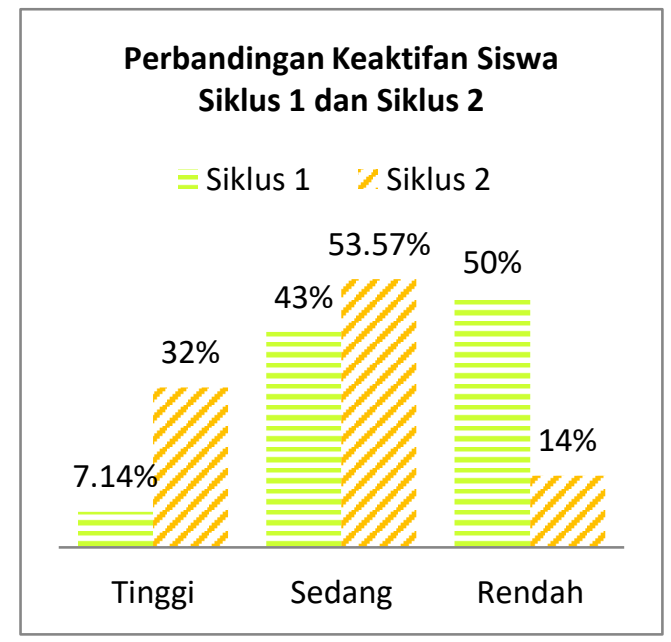

Gambar 2. Perbandingan Keaktifan Siswa

Salah satu faktor keberhasilan pembelajaran adalah kesiapan penyusunan perangkat pembelajaran yang sesuai. Guru menciptakan pembelajaran dengan berbagai aktifitas siswa sehingga membuat sebagian besar siswa aktif dan tetap fokus dalam pembelajaran. Desain belajar adalah salah satu faktor yang mempengaruhi konsentrasi belajar siswa (Tonienase 2007: 21). Proses diskusi dalam kelompok juga berjalan dengan baik, setiap anggota kelompok sungguh-sungguh di dalam diskusi dan mencatat hasil diskusi pada LKPD masing-masing. Hal ini dikarenakan adanya proses pemanggilan nomor dengan desain khusus sehingga peluang setiap siswa untuk terpilih besar. Penyampaian sintak yang menekankan informasi tentang pemanggilan nomor dan konsistensi guru dalam melaksanakannya dan dilengkapi dengan pemberian skor makin menyadarkan siswa untuk bersungguh-sungguh dalam 
diskusi. Dengan adanya tanggung jawab individu pada cooperative learning dapat meningkatkan diskusi sehingga berjalan dengan baik.

Siswa juga sudah terbiasa terpilih maju sehingga saat terpilih siswa sudah lebih percaya diri. Menurut Fatmala (2018), siswa yang memiliki rasa percaya diri akan mampu berbicara di depan banyak orang, berani mempertanggungjawabkan perkataan yang telah di ungkapkan, dan berusaha menyampaikan pendapatnya dalam berdiskusi. Selain itu, kekompakan antar anggota kelompok telah terbangun. Salah satu prinsip pembelajaran kooperatif adalah proses kelompok. Proses kelompok terjadi jika anggota kelompok mendiskusikan bagaimana mereka akan mencapai tujuan dengan baik dan membuat hubungan kerja yang baik.

Berdasarkan hasil penelitian di atas, dapat disimpulkan bahwa model NHT dapat meningkatkan hasil dan keaktifan belajar siswa dalam melaksanakan pembelajaran. Hasil penelitian ini membuktikan bahwa pentingnya pemilihan model pembelajaran yang tepat dalam melaksanakan proses belajar mengajar yang akan menghasilkan hasil optimal. Hal ini sejalan dengan hasil penelitian lainnya seperti penelitian yang dilakukan oleh Aniza (2017) terhadap siswa kelas VII materi perbandingan dengan permasalahan siswa tidak memahami konsep perbandingan, malu untuk bertanya dan mengemukakan pendapatnya, serta kurangnya rasa tanggung jawab terhadap tugas-tugas yang diberikan guru. Selain itu penelitian yang dilakukan oleh Destiyandani (2016) terhadap siswa kelas VII materi segitiga dengan permasalahan siswa kurang aktif bertanya saat merasa kesulitan, saat mendapat tugas yang dikerjakan siswa cenderung mengerjakan dengan melihat pekerjaan siswa lain, dan saat maju ke depan hanya siswa yang ingin maju. Kedua hasil penelitian ini menunjukkan bahwa model NHT dapat meningkatkan hasil belajar matematika siswa. Selain itu NHT juga telah terbukti dapat digunakan untuk meningkatkan keaktifan siswa, seperti yang disimpulkan oleh Maisyrah (2015) dan Sudarto (2017) berturut-turut pada materi bentuk akar dan logaritma pada siswa kelas $\mathrm{X}$ dan materi sifat pertukaran pada perkalian pada siswa kelas II.

\section{KESIMPULAN}

Penelitian ini telah menghasilkan hasil belajar dengan rata-rata kelas 81,2 dan presentasi ketuntasan sebesar 75\% serta keaktifan siswa dengan kategori minimal sedang mencapai $85,72 \%$ pada siklus 2 . Berdasarkan hasil tersebut dapat disimpulkan bahwa penerapan NHT pada materi segiempat dan segitiga dapat meningkatkan hasil dan keaktifan belajar siswa kelas VII H SMPN 6 Salatiga.

Berdasarkan penerapan NHT yang telah diuraikan dapat diketahui bahwa dalam menerapkan model NHT diperlukan teknik-tenik pembelajaran. Contohnya kekonsistenan penyampaian prosedur reward dan punishment dan juga pelaksanaan, serta perlu adanya strategi dalam pembagian kelompok yang tidak hanya memperhatikan nilai tetapi juga karakteristik siswa agar dapat membagi kelompok dengan tepat. Selain itu, adanya kegiatan-kegiatan atau aktivitas siswa yang bisa menjaga fokus siswa dalam belajar sehingga bisa menumbuhkan semangat siswa dalam belajar dan dapat terwujudnya suasana belajar yang lebih kondusif. 


\section{DAFTAR PUSTAKA}

Ali, Mohamad. (1987). Guru Dalam Proses Belajar Mengajar. Bandung: Sinar Baru

Alie. (2013). Penggunaan Model Pembelajaran Kooperatif Tipe NHT untuk Meningkatkan Hasil

Belajar Siswa Kelas X2 SMA Neg. 3 Gorontalo Pada Materi Jarak Pada Bangun Ruang. Jurnal Entropi, 08(1), 1-9. Dari: http://ejurnal.ung.ac.id/index.php/JE/article/view/1167/953

Aniza. (2017). Penerapan Model Pembelajaran Kooperatif Tipe Numbered Heads Together (NHT) untuk Meningkatkan Hasil Belajar Siswa Pada Materi Perbandingan di Kelas VII Tulip SMP Negeri 14 Palu. Jurnal Elektronik Pendidikan Matematika Tadulako, 04(3), 1-13. Dari: http://jurnal.untad.ac.id/jurnal/index.php/JEPMT/article/view/8450

Destiyandani, Era. 2016. Penerapan Model Pembelajaran Number Heads Together(Nht) Untuk Meningkatkan Hasil Belajar Siswa Kelas VIIA SMP Negeri 2 Tuntang Pada Materi Segitiga. Jurnal Penelitian Pengembangan Kependidikan, 32(2), 1-14. Dari: file:///C:/Users/USER.USER-PC/Downloads/721-Article\%20Text-1825-1-1020170217\%20(1).pdf

Djamarah, Syaiful Bahri dan Aswan Zain. (2010). Strategi Belajar mengajar. Jakarta: Rineka Cipta Fatmala, Lisa. (2018). Hubungan Antara Kepercayaan Diri dengan Prestasi Belajar Siswa Kelas VIII. Jurnal Bimbingan dan Konseling: 06(3), 1-15. Dari: http://jurnal.fkip.unila.ac.id/index.php/ALIB/article/view/16998

Hamdani. (2011). Strategi Belajar Mengajar. Bandung : Pustaka Setia

Hendriana, Heris, Euis Eti Roheati, dan Utari Sumarmo. (2018). Hard Skills dan Soft Skills Matematik Siswa. Bandung: Agung Ilmu

Kemendikbud. (2016). Permendikbud Nomor 22 tahun 2016 Tentang Standar Proses Pendidikan Dan Menengah. Jakarta: Kemendikbud

Nase, Tonie. (2007). Faktor yang Mempengaruhi Konsentrasi Belajar. Dari: http://www.psychologymania.com

Permendikbud. (2013). No. 70 tahun 2013 tentang Kerangka Dasar dan Struktur kurikulum SMK-MAK Rustaman. 2001. "Keterampilan Bertanya dalam Pembelajaran IPA." dalam Handout Bahan Pelantikan Guru-Guru IPA SLTP Se-Kota Bandung di PPG IPA. Jakarta: Depdiknas

Sani, Ridwan. (2013). Inovasi Pembelajaran. Jakarta: Bumi Aksara

Slavin, Robert E. (2005). Cooperative Learning: Teori Riset dan Praktik. Bandung: Nusa Indah

Sudarto. (2017). Peningkatan Aktivitas dan Hasil Belajar Matematika Melalui Model NHT Siswa Kelas II SDN Bonangrejo Semester 2 Tahun Pelajaran 2015/2016. Jurnal Eduaksi, Vol 04, No 01(14). Dari: https://jurnal.unej.ac.id/index.php/JEUJ/article/download/5077/3746/ (23 September 2019). 
Sukardi. (2013). Metode Penelitian Pendidikan Tindakan Kelas Implementasi dan Pengembangannya. Yogyakarta : Pustaka Pelajar

Trianto. (2009). Mendesain Model Pembelajaran Inovatif Progresif. Surabaya: Kencana Zamroni. (2000). Paradigma Pendidikan Masa Depan. Yogyakarta: Bigraf Pubilshing 